\title{
Perluasan Pengaturan Gadai \\ Setelah Dikeluarkannya Peraturan Otoritas Jasa Keuangan Tentang Usaha Pergadaian
}

\author{
Ni Putu Wahyu Mas Sanggia Suari ${ }^{1}$ \\ ${ }^{1}$ Program Studi Magister (S2) Kenotariatan Fakultas Hukum Universitas Udayana, Bali- \\ Indonesia, E-mail: gekwah22@yahoo.com
}

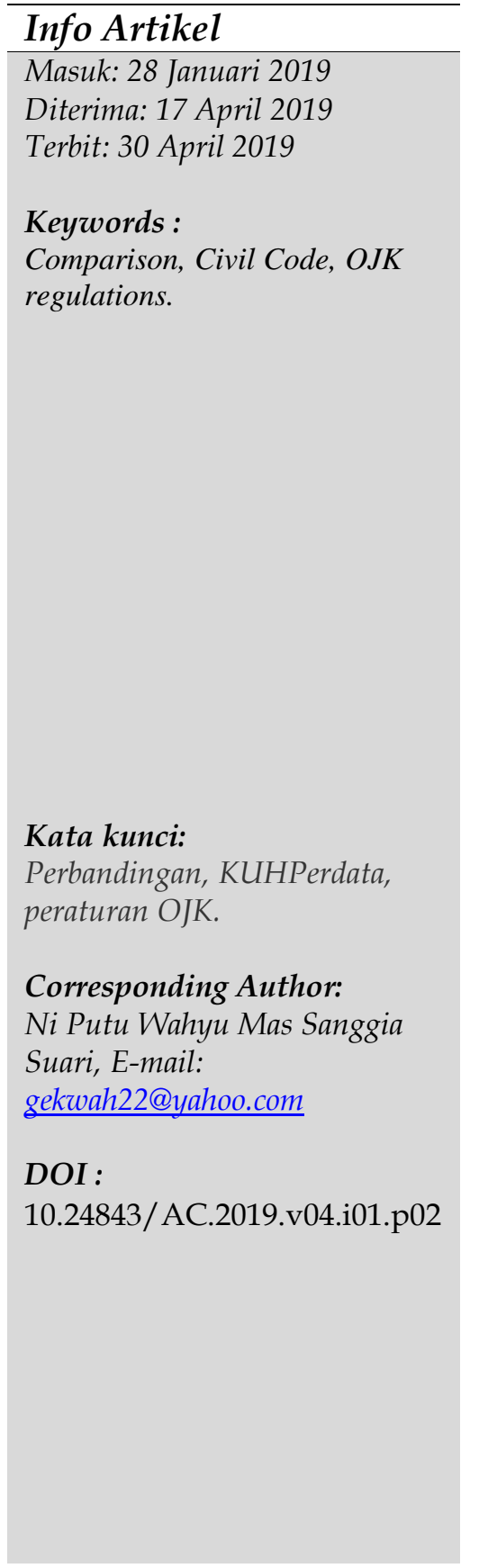

\begin{abstract}
Pawn arrangements in general are regulated in articles 11501160 of the civil code, this regulation its not enough to accommodate the provisions regarding mortgage after the rapid growth of business ventures. To accommodate this, the government issued a financial service authority regulation number: 31 / POJK.05 / 2016 concerning business ventures (POJK Pergadaian Business). This regulation aims to regulate in more detail about the business ventures which have still been a legal vacuum. The purpose of this writing is to find out a comparison of the pawn regulations regulated in the civil code and the regulations issued by the OJK regarding business ventures in which the detailed business arrangements are arranged. The research method used in this paper is a normative legal research method. The conclusion that can be drawn from this explanation is the mortgage in the civil code is a guarantee of material rights to a debt, in addition to pledges whose objects are movable or immovable objects, and with the existence of POJK about business ventures can provide more detailed arrangements regarding business ventures in Indonesia .
\end{abstract}

\section{Abstrak}

Pengaturan gadai secara umum diatur dalam pasal 11501160 KUHPerdata, peraturan ini belum cukup untuk mengakomodir ketentuan-ketentuan mengenai gadai setelah maraknya pertumbuhan usaha pergadaian yang cukup pesat. Untuk mengakomodirnya pemerintah mengeluarkan Peraturan Otoritas Jasa Keuangan nomor: 31/POJK.05/2016 tentang usaha pergadaian (POJK Usaha Pergadaian). Peraturan ini bertujuan untuk mengatur lebih rinci tentang usaha pergadaian yang selama ini masih terdapat kekosongan hukum. Penulisan ini bertujuan untuk mengetahui perbandingan mengenai peraturan gadai yang diatur dalam KUHPerdata dan peraturan yang dikeluarkan oleh OJK mengenai usaha pergadaian yang didalamnya diatur lebih rinci mengenai usaha pergadaian. Penulisan ini menggunakan metode penelitian hukum normatif. Kesimpulan yang dapat ditarik dari penjelasan ini adalah gadai dalam KUHPerdata adalah jaminan hak kebendaan atas suatu 
hutang, disamping gadai yang objeknya benda bergerak maupun benda tidak bergerak, serta dengan adanya POJK tentang usaha pergadaian dapat memberikan pengaturan lebih rinci mengenai usaha pergadaian di Indonesia.

\section{Pendahuluan}

Perkembangan globalisasi di era modern saat ini mengakibatkan meningkatnya kebutuhan masyarakat yang berdampak pada sistem perekonomian. Sistem perekonomian pada suatu daerah dapat diukur dari perputaran uangnya. Dalam hal memenuhi kebutuhan masyarakat yang meningkat, maka dana yang dibutuhkan yang cukup besarpula . Adapun cara memperoleh dana yang cukup besar, seseorang dapat melakukan perjanjian gadai dengan memenuhi beberapa persyaratan salah satunya dengan cara adanya penyerahan jaminan benda bergerak oleh pemberi gadai (debitur) kepada penerima gadai (kreditur) yang diatur dengan peraturan perundang-undangan yang berlaku di Indonesia. Jaminan jika ditelaah dengan menggunakan perspektif yuridis dimaknai sebagai salah satu upaya untuk memberikan kepastian hukum kepada kreditur bahwa debitur akan melaksanakan kewajibannya. ${ }^{1}$

Masyarakat umum dapat melakukan gadai karena tata tertib administrasi yang yang tidak rumit serta analisisnya lebih mudah dibandingkan dengan bentuk perjanjian seperti hak tanggungan ataupun jaminan fidusia. Perjanjian gadai lazim dilakukan dalam kehidupan sehari-hari dengan tujuan memperoleh pinjaman sejumlah uang dengan cara menyerahkan suatu barang sebagai jaminannya. Perjanjian gadai biasanya dilakukan oleh seseorang yang memiliki ekonomi yang lemah yang memerlukan dana untuk mendapatkan fasilitas kredit.

Pandangan masyarakat tentang gadai masih terjadi kekeliruan, gadai dipandang sebagai salah satu cara seseorang untuk mendapatkan utang. Hal ini terjadi dikarenakan barang yang dijaminkan oleh pemberi gadai harus ada terlebih dahulu dan dijadikan tolak ukur utama dan yang menentukan besar kecilnya jumlah utang.

Pada awalnya usaha gadai dijalankan oleh pihak swasta, namun seiring berjalannya usaha tersebut, kemudian diambil alih oleh pemerintahan hindia belanda yang selanjutnya diubah menjadi perusahaan Negara. ${ }^{2}$ Di Indonesia usaha gadai dibagi menjadi 2 (dua) macam yaitu pergadaian milik pemerintah dan pergadaian milik swasta. Adapun pihak yang memberikan gadai dikenal dengan sebutan pemberi gadai (debitur) sedangkan pihak yang menerima gadai dikenal sebagai pemegang gadai (kreditur). Masing-masing pihak tersebut memiliki hak dan kewajiban, apabila debitur tidak memenuhi kewajibannya sesuai dengan waktu yang telah ditentukan (wanprestasi), maka kreditur berhak untuk menjual benda yang digadaiakan tersebut, yang selanjutnya digunakan untuk membayar hutang dari debitur, apabila terdapat sisa hasil penjualan maka akan dikembalikan kepada debitur.

\footnotetext{
${ }^{1}$ Abubakar, L. (2015). Telaah Yuridis Perkembangan Lembaga dan Objek Jaminan (Gagasan Pembaruan Hukum Jaminan Nasional). Buletin Hukum Kebanksentralan, 12(1).

2 Pradica, M. I., 2018, Kedudukan Hukum Pergadaian Swasta Pasca Adanya Otoritas Jasa Keuangan Sebagai Pengawas Lembaga Keuangan, Universitas Jember.
} 
PT Pegadaian (persero) merupakan satu-satunya perusahaan gadai yang memiliki izin di Indonesia. PT Pegadaian (persero) Secara umum merupakan Badan Usaha Milik Negara (BUMN) yang bergerak di bidang jasa dan satu-satunya badan usaha di Indonesia yang telah resmi memiliki izin untuk melaksanakan kegiatan lembaga keuangan berupa pembiayaan masyarakat berdasarkan hukum gadai.

PT Pegadaian (persero) melakukan pertanggungjawaban dalam hal kinerja manajer agar menjadi lebih baik dan terus melakukan perbaikan pada penerapan akuntansi. Oleh karena itu setiap akhir tahun, perusahaan membuat RKAP (rencana kerja dan anggaran perusahaan) sehingga perusahaan dapat mengetahui selisih perbandingan proyeksi lama atau rugi. ${ }^{3}$ Dasar hukum pegadaian di Indonesia adalah Peraturan Pemerintah Republik Indonesia Nomor 103 Tahun 2000 yang telah diperbaharui yaitu Peraturan Pemerintah Nomor 51 Tahun 2011 tentang Perubahan Bentuk Badan Hukum Perusahaan Umum Pegadaian Menjadi Perusahaan Perseroan.

Pengaturan gadai telah lama diatur dalam Kitab Undang-Undang Hukum Perdata (selanjutnya disingkat KUHPedata). Namun seiring dengan perkembangan zaman saat ini dan kebutuham masyarakat yang semakin meningkat maka pada tahun 2016 pemerintah menerbitkan aturan baru yaitu Peraturan OJK Nomor: 31/POJK.05/2016 Tentang Usaha Pergadaian (selanjutnya disingkat POJK Usaha Pergadaian), peraturan ini menjadi dasar keberadaan perusahaan gadai swasta. Peraturan ini oleh Otoritas Jasa Keuangan (selanjutnya disingkat OJK), ditujukan untuk mengisi kekosongan hukum mengenai usaha pergadaian yang selama ini belum diatur secara lebih rinci.

Beberapa jaminan kebendaan di Indonesia telah diatur dengan peraturan perundangundangan, contohnya Jaminan Fidusia (UU Nomor 42 tahun 1999), dan Hak Tanggungan ( UU Nomor 4 Tahun 1996). Pengaturan Gadai masih mengacu pada Buku II KUHPerdata yaitu Pasal 1150-1160. Sedangkan PP Nomor 51 Tahun 2011) khusus mengatur mengenai PT Pegadaian (persero) sebagai usaha pergadaian pemerintah dan tidak menunjuk pada usaha pergadaian secara umum.

Pengaturan gadai memiliki (dua) rezim pengaturan pertama, pengaturan perusahaan gadai milik Negara yaitu PT Pegadaian (persero) yang diatur melalui Peraturan Pemerintah, yang kedua pengaturan perusahaan gadai milik swasta yang diatur melalui POJK Usaha Pergadaian. Perbedaan pengaturan tersebut menyebabkan terjadinya perbedaan strata pengaturan untuk materi muatan yang sama yakni mengenai perusahaan gadai. 4 Dengan adanya perbedaan materi muatan dalam perusahaan gadai, maka akan menimbulkan konsekuensi hukum yang berbeda.

Penjabaran pada POJK Usaha pergadaian, mengenai status atau kedudukan hukum pegadaian pada saat ini adalah PT Pegadaian (persero) lebih tepatnya terdapat pada Pasal 1 angka 4 Peraturan Otoritas Jasa Keuanagan, perusahaan pergadaian

\footnotetext{
${ }^{3}$ Mengko, N. C. (2013). Penerapan Akuntansi Pertanggungjawaban Untuk Penilaian Kinerja Nonfinansial Kantor Wilayah VI PT. Pegadaian (Persero). Jurnal EMBA: Jurnal Riset Ekonomi Manajemen, Bisnis dan Akuntansi, 1(4).

${ }^{4}$ Hanifah, A., Santoso, B. S., \& Navianto, I. (2018). URGENSI PENGATURAN PERUSAHAAN GADAI SWASTA DENGAN SISTEM ONLINE. Al-mustashfa: jurnal penelitian hukum ekonomi syariah, 3 (1), 30-41.
} 
pemerintah adalah PT Pegadaian (persero), yang mana kegiatan usaha PT pegadaian diantaranya sebagai penyalur uang pinjaman dengan menggunakan jaminan yang berdasarkan atas hukum gadai, sebagai penyalur uang pinjaman dengan menggunakan jaminan fidusia, pelayanan jasa titipan barang berharga, dan/atau pelayanan jasa taksiran. Perusahaan pergadaian dapat melakukan kegiatan usaha lainnya yang diatur dalam Pasal 13 ayat (2) huruf b POJK Usaha Pergadaian.

Usaha pergadaian yang dikeluarkan oleh OJK memiliki ruang lingkup yang lebih luas dibandingkan dengan ketentuan yang terdapat pada Pasal 1150 KUHPerdata. POJK Usaha Pergadaian telah memasukkan usaha pergadaian dengan menggunakan prinsip syariah. Ruang lingkup pergadaian tidak hanya mengacu pada PT Pegadaian yang dimiliki oleh pemerintah saja, namun juga mencakup perusahaan swasta. Beranjak dari penjabaran diatas, penulis tertarik untuk mengangkat judul mengenai Perbandingan Pengaturan Gadai Setelah Dikeluarkannya Peraturan Otoritas Jasa Keuangan Tentang Usaha Pergadaian.

\section{Metode Penelitian}

Penelitian ini merupakan penelitian hukum normatif. Penelitian hukum normatif adalah penelitian untuk menemukan asas-asas hukum berdasarkan pada kaidah hukum atau norma-norma dalam peraturan perundang-undangan. Metode penelitian ditulis dengan bab tersendiri setelah bab pendahuluan. Dengan menggunakan pendekatan perundang-undangan (the statute approach), dan pendekatan konsep (the conseptual approach). Sumber bahan hukum yang digunakan adalah sumber bahan hukum primer, sumber bahan hukum sekunder, dan sumber bahan hukum tertier yaitu pendukung sumber bahan hukum primer dan sekunder. Teknik pengumpulan bahan hukum yang digunakan adalah teknik studi dokumen, merupakan teknik awal yang digunakan dalam setiap penelitian ilmu hukum. Teknik studi dokumen dikaitkan pada alat suatu pengumpulan data yang dilakukan melalui data tertulis dengan menggunakan content analysis.5 Teknik analisis yang digunakan yaitu teknik analisis deskriptif dan teknik sistematis.

\section{Hasil dan Pembahasan}

\subsection{Pengaturan Gadai secara umum Yang Terdapat Pada KUHPerdata}

Istilah gadai dalam bahasa Belanda disebut pand atau dalam bahasa Inggris disebut pledge. Secara umum gadai tercandum dalam Buku II pada Bab XX Pasal 1150-1160 KUHPerdata. Gadai merupakan bentuk perjanjian pinjam meminjam, pinjam meminjam yang dilakukan dengan sistem gadai dianggap lebih praktis oleh masyarakat karena dalam pelaksanaannya, penjaminan dengan gadai tidak melalui tahap yang panjang.

Rumusan Pasal 1313 KUHPerdata menyatakan bahwa perjanjian gadai berdasarkan atas kesepakatan dari para pihak yaitu si pemberi gadai (debitur) dengan si penerima gadai (kreditur) untuk mengikatkan dirinya. Perjanjian gadai yang dilakukan antara debitur dengan kreditur akan menimbulkan hak dan kewajiban. Hak dan kewajiban

\footnotetext{
${ }^{5}$ Soerjono Soekanto, 2014, Pengantar Penelitian Hukum, Cet. III, Universitas Indonesia (UI-PRESS), Jakarta, hal. 21.
} 
yang timbul bagi para pihak dalam gadai didasari karena adanya hubungan hukum. Hubungan hukum dapat menimbulkan akibat hukum bagi perjanjian yang telah dibuat.

Dalam gadai terdapat dua subjek hukum yang saling berkaitan erat yaitu pemberi gadai (pihak yang menggadaikan) serta penerima gadai (penerima atau pemegang gadai). Gadai termasuk kategori perjanjian accessoir (tambahan), sedangkan pinjam meminjam uang dengan jaminan benda bergerak adalah perjanjian pokoknya. Benda bergerak pada dasarnya dapat dibagi menjadi dua golongan yaitu benda bergerak berwujud dan benda bergerak tidak berwujud.

Rumusan Pasal 1150 KUHPerdata menyatakan bahwa gadai merupakan suatu hak terhadap benda jaminan gadai yang bergerak, dimana benda jaminan yang bergerak tersebut diserahkan oleh debitur atau oleh orang yang ditunjuk sebagai kuasa kepada kreditur. Saat benda gadai dikuasai oleh kreditur, maka benda gadai tersebut dapat digunakan sebagai jaminan untuk hal pelunasan utang-utang debitur dan apabila debitur melakukan wanprestasi, yang mana benda jaminan gadai ini sebagai pelunasan yang harus didahulukan dari pada pelunasan utang terhadap kreditur lainnya. Kreditur lainnya yang dimaksud apabila debitur mempunyai utang terhadap lebih dari satu kreditur.

Bentuk jaminan yang tidak akan menghambat kegiatan usaha yang dikerjakan seharihari merupakan bentuk jaminan yang baik bagi pihak debitur sedangkan jaminan yang dapat memberikan rasa aman dan kepastian hukum bahwa kredit yang diberikan dapat diperoleh kembali tepat pada waktunya merupakan bentuk jaminan yang baik bagi kreditur. ${ }^{6}$

Pasal 1151 KUHPerdata, menjelaskan bahwa perjanjian gadai harus dibuktikan dengan alat yang dapat membuktikan perjanjian pokoknya. Penyerahkan gadai kepada kekuasaan kreditur dilakukan untuk jaminan gadai dengan barang bergerak baik yang berwujud dan atas piutang bawa timbul (Pasal 1152 KUHPerdata).

Hak gadai dikatakan hapus apabila gadai itu terlepas dari kekuasaan si pemegang gadai. Apabila barang itu hilang, atau kekuasaannya diambil alih, maka ia berhak untuk menuntutnya kembali menurut Pasal 1977 alenia kedua, dan hak gadai dianggap tidak pernah hilang, apabila hak gadai itu telah kembali kepada si pemegang gadai. Tidak adanya wewenang pemberi gadai untuk bertindak bebas atas barang itu, tidak dapat dipertanggungjawabkan kepada kreditur, tanpa mengurangi hak orang yang telah kehilangan atau kecurigaan barang itu untuk menuntutnya kembali.

Adapun sifat-sifat dari benda gadai antara lain:

1. Bersifat accesoir yaitu perjanjian tambahan dari perjanjian pokoknya yaitu perjanjian pinjaman uang;

2. Benda gadai dikatakan sebagai hak yang bersifat memberikan jaminan serta menjamin pembayaran kembali dari uang pinjaman itu;

\footnotetext{
${ }^{6}$ Winarno, J. (2013). Perlindungan Hukum bagi Kreditur pada Perjanjian Jaminan Fidusia. Jurnal Independent, $1(1)$.
} 
3. Suatu hak untuk menguasai barang tidak termasuk hak untuk menikmati, hak untu memakai, dan hak untuk memungut hasil barang yang digunakan sebagai jaminan;

4. Gadai tidak dapat dibagi, artinya hak gadai tidak hapus apabila telah dibayarnya sebagian dari utang gadai, gadai tetap melekat atas seluruh bendanya.

Pasal 1155 KUHPerdata mengatur mengenai hak dan kewajiban pemberi dan penerima gadai. Hak dan kewajiban para pihak timbul Sejak terjadinya perjanjian gadai antara pemberi gadai dengan penerima gadai. Adapun Hak penerima gadai yaitu Menjual barang gadai, apabila pemberi gadai melanggar kewajibannya dan tidak sesuai dengan waktu yang telah ditentukan, Menerima pembayaran pinjaman serta bunga sesuai dengan waktu yang telah ditentukan.

Pasal 1154, Pasal 1156, dan Pasal 1157 KUHPerdata mengatur mengenai Kewajiban penerima gadai. Adapun kewajiban penerima gadai yaitu, Dilarang mengalihkan barang yang digadaikan menjadi miliknya, merawat serta menjaga barang gadai, Bertanggungjawab apabila terjadi kerugian atau susutnya barang gadai akibat kelalaiannya, dan melaporkan kepada pemberi gadai apabila ingin melakukan pemindahan barang gadai.

Hak-hak pemberi gadai yaitu menerima sejumlah uang dari penerima gadai, Memiliki hak untuk menuntut kepada pengadilan agar barang gadai dijual untuk melunasi hutang-hutangnya, memiliki hak atas barang gadai, apabila hutang pokok, bunga dan biaya lainnya telah dibayarkan dengan lunas.

Kewajiban pemberi gadai yaitu, menyerahkan barang yang telah digadaikan kembali kepada penerima gadai, membayar biaya yang dikeluarkan oleh penerima gadai untuk menyelamatkan barang-barang gadai, membayar uang pokok serta uang sewa modal kepada penerima gadai.

Dalam perjajian gadai terdapat dua pihak yaitu dilakukan oleh debitur dan kreditur dengan adanya penyerahan benda jaminan yaitu berupa benda bergerak, dimana saat penguasaan benda jaminan gadai dikuasai oleh kreditur. Dalam praktiknya tentu perjanjian gadai yang dilakukan antara debitur dan kreditur terdapat adanya hambatan yang tidak dapat dihindarkan, misalnya terjadinya keadaan memaksa (force majeur). Force majeur adalah keadaan yang terjadi setelah dibuatnya suatu perikatan dan diluar kehendak debitur, dimana debitur tidak dapat memprediksi terlebih dahulu risiko-risiko yang akan terjadi pada saat dibuatnya suatu perikatan. Misalnya terjadi bencana alam, kerusuhan, dan perang.

Pasal 1157 KUHPerdata mengatur mengenai pertanggungjawaban kreditur apabila terjadi kerugian dan susutnya barang gadai atas kelalaiannya. Disisi lain debitur memiliki kewajiban untuk mengganti biaya yang perlu dikeluarkan kreditur untuk menyelamatkan jaminan gadai.

Kemudian Pasal 1245 KUHPerdata menjelaskan bahwa apabila terjadi keadaan memaksa atau karena sesuatu dan lain hal yang terjadi secara tidak sengaja, maka 
tidak ada penggantian biaya kerugian atau bunga. Berdasarkan Pasal 1157 KUHPerdata hanya mengatur mengenai tanggung jawab kreditur apabila terjadi kerugian terhadap benda gadai akibat kelalaiannya. Dalam Pasal 1245 KUHPerdata hanya mengatur bahwa kreditur tidak mempunyai tanggungjawab terhadap benda gadai yang mengalami kerugian akibat keadaan memaksa. Pada Bab XX Pasal 11501160 KUHPerdata yang mengatur mengenai Gadai tidak menjelaskan benda jaminan gadai yang musnah akibat keadaan memaksa.

Dalam Pasal 1157 KUHPerdata mengatur mengenai kerugian atau susutnya barang gadai akibat dari kelalaiannya dan ditanggung oleh kreditur. Pasal 1157 KUHPerdata itu hanya mengatur bahwa kreditur bertanggung jawab apabila terjadi kerugian benda gadai apabila akibat kelalaian kreditur. Dalam BAB XX KUHPerdata tidak mengatur benda jaminan gadai yang musnah akibat force majeur.

\subsection{Perluasan Pengaturan Gadai Setelah Dikeluarkannya POJK Tentang Usaha Pergadaian}

Undang-Undang OJK telah mengatur bahwa pergadaian adalah lembaga jasa keuangan yang berada dalam pengaturan dan pengawasan oleh OJK. Terkait dengan perjanjian gadai, saat ini telah diterbitkan tentang Usaha Pergadaian (POJK Usaha Pergadaian) yang telah memberikan pengaruh terhadap regulasi hukum jaminan salah satunya jaminan gadai sebagai jaminan kebendaan di Indonesia. Perusahaan pergadaian dibagi menjadi dua yaitu perusahaan pergadaian yang dikelola oleh swasta dan perusahaan pergadaian yang dikelola oleh pemerintah dibawah pengawasan OJK (Pasal 1 angka 2 POJK Usaha Pergadaian). Penjelaskan lebih lanjut mengenai perusahaan pergadaian dapat dibagi menadi dua yaitu :

1. Perusahaan pergadaian swasta

Pasal 1 angka 3 POJK Usaha Pergadaian mengatur tentang perusahaan pergadaian yang melakukan usaha pergadaian dan berbentuk badan hukum. Usaha pergadaian yang dimaksud dalam POJK Usaha pergadaian lingkupnya lebih luas dibandingkan dengan apa yang dijelaskan pada Pasal 1150 KUHPerdata. Dalam peraturan tersebut sudah memasukkan jenis usaha pergadaian dalam bentuk syariah. Lingkup perusahaan pergadaian pun tidak lagi hanya tertuju pada PT. pergadaian yaitu perusahan pergadaian pemerintah, tetapi juga perusahan swasta.

2. Perusahaan pergadaian pemerintah

Pasal 1 angka 4 POJK Usaha Pergadaian mengatur tentang PT Pegadaian (persero) yang merupakan perusahaan pergadaian pemerintah. Sebelumnya keluarnya POJK Usaha pergadaian, hukum positif di Indonesia yang mengatur tentang gadai adalah Pasal 1150-1160 KUHPerdata. Makna gadai sebagai jaminan kebendaan dalam KUHPerdata yang bersifat accessoir, dimana lahir dan hapusnya gadai bergantung pada perjanjian pinjam meminjam yang termasuk dalam perjanjian pokoknya.7

Makna gadai yang diatur pada KUHPerdata lingkup nya lebih sempit dibandingkan dengan lingkup usaha pergadaian yang diatur pada Pasal 1 angka 1 POJK, karena

\footnotetext{
${ }^{7}$ Abubakar, L., \& Handayani, T. (2018). Telaah Yuridis Perkembangan Regulasi Dan Usaha Pergadaian Sebagai Pranata Jaminan Kebendaan. Jurnal Bina Mulia Hukum, 2(1).
} 
dalam POJK membahas mengenai jasa taksiran, jasa titipan, dan jasa-jasa lainnya berdasarkan pinsip syariah. Sebelum diterbitkannya peraturan ini, praktik gadai berkembang tanpa adanya pengawasan serta regulasi yang kurang memadai, sehingga menimbulkan ketidakpastian hukum bagi pihak yang ini menggadaikan barangnya dan perlindungan hukum terhadap para konsumen yang ingin menggadaikan barangnya.

Terbitnya POJK Usaha Pergadaian ini akan menjadi landasan hukum yang kuat bagi OJK dalam melakukan pengawasan terhadap usaha pergadaian sebagai salah satu industri jasa keuangan khusus. ${ }^{8}$ Unsur-unsur gadai yang terdapat dalam POJK sama dengan unsur gadai yang terdapat pada KUHPerdata yaitu kedudukan gadai sebagai jaminan kebendaan. Pada Pasal 1150 KUHPerdata terdapat unsur-unsur gadai diantaranya :

1. Penguasaan barang (bergerak) berada di tangan kreditur atau perusahaan pegadaian;

2. Dalam hal nasabah tidak dapat membayar pinjamannya, perusahaan pergadaian dapat mengambil pelunasan dari hasil lelang atau penjualan barang bergerak tersebut;

3. Perusahaan pergadaian selaku kreditor mempunyai hak untuk didahulukan (droit de preference) dari kreditor lainnya.

Adapun dalam hal ini akan dijelaskan mengenai perbedaan gadai yang diatur dalam KUHPerdata dengan POJK Usaha Pergadaian. Mengenai objek gadai, dalam KUHPerdata yang menjadi objek gadai adalah benda bergerak yang berwujud ataupun yang tidak berwujud. Sedangkan dalam gadai POJK, objek gadai adalah benda bergerak saja. Penguasaan barang gadai dalam KUHPerdata dipegang oleh penerima gadai, sedangkan penguasaan barang gadai dalam POJK di dipegang oleh perusahaan pegadaian. Hak penerima gadai dalam KUHPerdata dilakukan dengan cara mengambil pelunasan utang dari objek gadai, sedangkan dalam gadai POJK, dilakukan dengan cara mengambil pelunasan pinjaman dari barang gadai. Selanjutnya mengenai status barang gadai, dalam KUHPerdata dikuasai dan menjadi milik debitor, sedangkan dalam gadai POJK dikuasai dan menjadi milik nasabah. Yang terakhir mengenai keuntungan, dalam KUHPerdata hanya mengatur mengenai bunga dan biaya lain lain saja, sedangkan dalam gadai POJK mengatur mengenai bunga dan jasa pinjaman.

Ketentuan mengenai gadai yang terdapat di dalam penjelasan pasal 1150-1160 KUHPerdata kurang sesuai dengan perkembangan jaman masa kini. Ada beberapa peraturan mengenai gadai yang tidak diatur dalam KUHPerdata tetapi diatur dalam POJK Usaha Pergadaian misalkan saja pada Pasal 22 ayat (3) POJK menjelaskan bahwa barang jaminan dan barang titipan wajib diasuransikan oleh perusahaan pergadaian berdasarkan hukum gadai untuk mengintimigasi risiko. Upaya untuk meminimalisir risiko yang mungkin akan terjadi, setiap individu tentu mempunyai pilihan masing-

\footnotetext{
${ }^{8}$ Perusahaan-perusahaan yang termasuk dalam industry jasa keuangan khusus didirikan dengan tujuan khusus untuk membantu mensukseskan program-program pemerintah dalam rangka meningkatkan kapasitas perekonomian nasioan, lihat OJK, laporan triwulan-triwulan I-2017, hal. 34.
} 
masing, yang pada umumnya tidak dikelola sendiri akan tetapi ke pihak lain, dalam hal ini ke lembaga asuransi. ${ }^{9}$

Dalam hal ini sangat penting bagi perusahaan mengasuransikan jaminan gadai yang dititipkan kepadanya, karena apabila terjadi sesuatu yang tidak diinginkan yakni gunung meletus, tsunami, angin topan dan lain sebagainya, barang jaminan gadai akan tetap aman karena adanya asuransi yang menanggungnya. Terjadinya gunung meletus, tsunami mapun angina topan, dalam hukum termasuk kedalam kategori keadaan memaksa (force majeur).

Selanjutnya mengenai jangka waktu pinjaman dengan penggunaan jaminan gadai yang diatur pada Pasal 24 ayat (1) POJK paling lama 4 (empat) bulan, namun pada KUHPerdata tidak dijelaskan lebih rinci megenai jangka waktu pinjaman gadai dari pemberi gadai kepada penerima gadai.

Pasal 26 POJK menjelaskan mengenai tata cara serta syarat-syarat penjualan barang jaminan dengan cara lelang sesuai dengan peraturan perundang-undangan. Dipertegas lagi oleh Pasal 27 yaitu mengembalikan uang kelebihan dari hasil penjualan barang jaminan oleh perusahaan gadai yang diwajibkan dengan cara lelang atau berdasarkan kuasa menjual. Dalam KUHPerdata tidak diatur secara lebih rinci mengenai penjualan barang jaminan dengan cara lelang.

Peraturan ini juga menyebutkan tentang ruang lingkup kegiatan usaha gadai yang diselenggarakan dengan menggunakan prinsip syariah ataupun konvensional, yaitu:

1. Menyalurkan uang pinjaman dengan jaminan berdasarkan fidusia;

2. Menyalurkan uang pinjaman berdasarkan hukum gadai;

3. Melayani penitipan barang-barang berharga;

4. Melayani jasa taksiran;

5. Kegiatan- kegiatan lain yang berdasarkan atas fee based income;

6. Kegiatan- kegiatan lain yang diselenggarakan atas persetujuan OJK.

\section{Kesimpulan}

Pengaturan gadai secara umum diatur pada Pasal 1150-1160 KUHPerdata. Terdapat 2 (dua subjek hukum dalam gadai yaitu pemberi gadai (debitur) dan penerima gadai (kreditur). Objek jaminan gadai dibagi menjadi dua jenis yaitu jaminan benda bergerak dan jaminan benda tidak bergerak. Apabila debitur melakukan wanprestasi, maka kreditur berhak untuk menjual atau melelang barang jaminan gadai dan apabila dalam penjualan tersebut terdapat sisa, maka akan dikembalikan kepada pemberi gadai. Adapun sifat-sifat benda gadai yaitu bersifat accesoir, merupakan hak yang bersifat memberi jaminan, tidak dapat dibagi-bagi, dan hak untuk menikamati tidak termasuk hak menguasai barang, memakai, ataupun memungut hasil.

Dikeluarkanya Peraturan OJK tentang Usaha Pergadaian (POJK Usaha Pergadaian) yang telah memberi pengaruh terhadap regulasi hukum jaminan salah satunya

\footnotetext{
9 Sembiring S, 2014, Hukum Asuransi, Nuansa Aulia, Bandung, hal. 4.
} 
jaminan gadai sebagai jaminan kebendaan di Indonesia. Dalam peraturan ini mengatur lebih rinci mengenai usaha pergadaian swasta maupun usaha pergadaian pemerintah, serta memberikan terobosan baru terhadap pengaturan gadai yang pada umumnya diatur dalam KUHPerdata. Salah satunya adalah wajib mengasuransikan barang jaminan gadai, untuk meminimalisir risiko yang mungkin akan timbul di kemudain hari, serta mengatur mengenai jangka waktu pinjaman gadai, dan tata cara penjualan barang jaminan gadai.

\section{Daftar Pustaka}

Buku

S, Sembiring, (2014). Hukum Asuransi. Bandung: Nuansa Aulia.

Soekanto, Soerjono. (2014). Pengantar Penelitian Hukum. Cet. III. Jakarta: Universitas Indonesia (UI-PRESS).

\section{Jurnal}

Mengko, N. C. (2013). Penerapan Akuntansi Pertanggungjawaban Untuk Penilaian Kinerja Nonfinansial Kantor Wilayah VI PT. Pegadaian (Persero) Manado. Jurnal EMBA: Jurnal Riset Ekonomi, Manajemen, Bisnis dan Akuntansi, 1(4).

Hanifah, A., Santoso, B. S., \& Navianto, I. (2018). Urgensi Pengaturan Perusahaan Gadai Swasta Dengan Sistem Online. Al-Mustashfa : Jurnal Penelitian Hukum Ekonomi Syariah, 3(1), 30-41.

Abubakar, L., \& Handayani, T. (2018). Telaah Yuridis Perkembangan Regulasi Dan Usaha Pergadaian Sebagai Pranata Jaminan Kebendaan. Jurnal Bina Mulia Hukum, 2(1).

Abubakar, L. (2015). Telaah Yuridis Perkembangan Lembaga dan Objek Jaminan (Gagasan Pembaruan Hukum Jaminan Nasional). Buletin Hukum Kebanksentralan, 12(1).

Winarno, J. (2013). Perlindungan Hukum Bagi Kreditur Pada Perjanjian Jaminan Fidusia. Jurnal Independent, 1(1).

Perusahaan-perusahaan yang termasuk dalam industri jasa keuangan khusus didirikan dengan tujuan khusus untuk membantu mensukseskan programprogram pemerintah dalam rangka meningkatkan kapasitas perekonomian nasioal, lihat OJK, laporan triwulan-triwulan I-2017, hal. 34.

\section{Tesis/Disertasi}

Pradica, M. I., (2018). Kedudukan Hukum Pergadaian Swasta Pasca Adanya Otoritas Jasa Keuangan Sebagai Pengawas Lembaga Keuangan. Universitas Jember.

\section{Peraturan Perundang-Undangan}

Kitab Undang-Undang Hukum Perdata (Burgerlijk Wetboek), 2014, Diterjemahkan Oleh Soedharyo Soimin, Cetakan Ke-13, Sinar Grafika, Jakarta.

Peraturan Otoritas Jasa Keuangan Nomor: 31/POJK.05/2016 tentang Usaha Pergadaian (POJK Usaha Pergadaian) Lembaran Negara Republik Indonesia Tahun 2016 Nomor 152. 